The University of Akron

\title{
IdeaExchange@UAkron
}

Proceedings from the Document Academy

University of Akron Press Managed

December 2016

\section{"Windows" of Time, Part II: Documenting Temporal and Embodied Epistemology in Musicians}

Lynnsey K. Weissenberger

Florida State University, 1ks03d@my.fsu.edu

Please take a moment to share how this work helps you through this survey. Your feedback will be important as we plan further development of our repository.

Follow this and additional works at: https://ideaexchange.uakron.edu/docam

Part of the Library and Information Science Commons, and the Music Commons

\section{Recommended Citation}

Weissenberger, Lynnsey K. (2016) "“'Windows" of Time, Part II: Documenting Temporal and Embodied Epistemology in Musicians," Proceedings from the Document Academy: Vol. 3 : Iss. 2 , Article 19.

DOI: https://doi.org/10.35492/docam/3/2/19

Available at: https://ideaexchange.uakron.edu/docam/vol3/iss2/19

This Conference Proceeding is brought to you for free and open access by University of Akron Press Managed at IdeaExchange@UAkron, the institutional repository of The University of Akron in Akron, Ohio, USA. It has been accepted for inclusion in Proceedings from the Document Academy by an authorized administrator of

IdeaExchange@UAkron.For more information, please contact mjon@uakron.edu, uapress@uakron.edu. 


\section{"Windows" of Time, Part II: Documenting Temporal and Embodied Epistemology in Musicians}

[Note: This paper is an extension to the earlier paper "Windows" of Time: Memory, Metaphor, and Storytelling as Documents, published in the Proceedings from the Document Academy 3(1).]

\section{Introduction}

Discussed within the first part of "Windows" of Time, (Weissenberger, 2016), an exploratory study of 11 music practitioners' perceptions and characterizations of musical knowledge versus music information yielded the discovery of musicians' "temporal epistemology." Temporal Epistemology is a term that refers to ways of knowing and coming to know that vary over time, using various socio-cognitive devices to denote, construct, and re-construct epistemic perspectives of time. For music practitioners in particular, memories, metaphors and stories act as documents that provide "windows" into this process (more can be found within Weissenberger 2015 and 2016).

Temporal epistemology incorporates music practitioners' non-linearity of time within musical experience, the ongoing process of music making, and both the acquisition and transmission of musical knowledge. Memory, metaphor, and storytelling as documents emerged and were used in three contexts: music performances; teaching and transmission; and, to mark the ongoing process of knowledge building. An example of each of these are recapitulated in the following sections, summarized from part I of "Windows" of Time.

\section{Performance}

Within music performance contexts, the Chinese zheng and guquin musician noted her memories of a teacher are manifest in the present when she is performing a particular piece strongly associated with this teacher:

Another level is the personal feeling, you know... a lot of pieces are associated with memories...for myself...when I play it doesn't communicate to other people but it communicate[s] with me. Like, there's one piece I play that - every time I play - I will think of my teacher, in middle school/high school, my first teacher, you know, and we are still very 
good friends. I have very deep feeling with her, and we're like sisters. So, I remember when I was younger, when I first learned this piece, I just listened to her CD again and again and again... and cry...you know, it was very emotional...and still it strikes very deep within me. So definitely, my memory with this music involves a lot with this personal feeling with her.

Performance is a particularly heightened activity, making it prone to temporal fluctuations, evoking memories, or other ways of documenting this shift: "The activities of remembering which attract our attention often occur in a heightened, affectively saturated present. Yet whether effortful or involuntary, whether explicit or tacit, memory also refers to, enlivens, or otherwise renders salient many other moments" (Tribble \& Sutton, 2012, p. 589).

\section{Teaching \& Transmission}

Within teaching and transmission contexts, the Indian Carnatic and Hindustani sitar and tabla player described the older traditional teaching approach, Guru Karavas:

Our training is more like guru karavas. Guru karavas means you're living and breathing the guru's house. You eat there, you spend... In those days, many years ago, they would leave kids in the guru's house and go away. The children trained there for many years. It's like a conservatory or whatever you call it. And they do little chores in the house and the teacher feeds them and does everything...this was in olden times, not now. Probably centuries ago. And yes, so they stay in the guru's house, they learn everything, and finally when they get ready to perform the guru takes them with him and allows them to perform in their concerts, and gives them the experience, and finally lets them go...you know, and then they go home, do whatever they have to do, and flourish.

In this memory, she describes the approach used by her Indian teachers, which was a modernized Guru Karavas, contrasted by the more rushed mindset of her American students:

Fortunately, none of my teachers rushed, ok? A lot of students nowadays feel that they must have a book FULL of ragas; a book full of compositions. Only then do you know you have learned a lot. I...ah, 
thankfully, my teachers were not like that. So if you picked a scale, we did it very well for almost a year or two, I mean, we'd still just dwell on it. So I learned the [raga] for one and a half years. That's all we did. Explored the scale...did a lot of Alaps. Which - alaps means the very slow exploration of the scale. Very slow. Then you get into the absolute, under-the-skin of every note, and you play it. ... So, I learned that for one and a half years with him, and - to this day - I don't think I have forgotten a nuance of that scale that he taught me.

\section{Knowledge Building}

In knowledge-building and sharing contexts, temporal epistemology accounts for musical knowledge that is 1) temporary and dynamic 2) bound/encapsulated by time, as well as 3) re-defined, re-negotiated, and rematerialized at various points in time. These three aspects of temporal epistemology in practice means examining practitioners' memories, stories, and - particularly when describing aspects of cultural knowledge - metaphors of knowledge creation, use, and sharing. More related to knowledge building and temporal epistemology is discussed within the next section on Irish traditional music.

\section{Temporal Epistemology in Irish Traditional Music}

One musical tradition, in this case Irish traditional music, is used as a kind of case study to examine how temporal epistemology (as well as the relationship to embodied knowledge) is manifest within this orally-based tradition and the ways in which it is documented by practitioners. Excerpts are taken from an interview with a renowned Clare-style Irish fiddler conducted as a part of the research study from Part 1 of this paper, along with excerpts from auto-biographical and reflexive texts published by notable Irish traditional musicians Ciaran Carson, Séamus Ennis, Tomás Ó Canainn, and Micheál Ó Súilleabháin.

Ciaran Carson, author of Last Night's Fun: In and Out of Time with Irish Music (1996) uses his book as one overarching reflexive narrative containing many smaller stories and memories, with these anecdotes containing many metaphorical and philosophical insights into the practice of Irish traditional music. Chapter 1 is titled "Last Night's Fun" after a well-known traditional reel that features as the center of Carson's story, his memories (along with several interjections) and 
associations with the tune feature the solo album of the late, renowned accordion player Joe Cooley.

In the preface, Carson quotes a poem by piper, and early collector of traditional music and song for the Irish Folklore Commission, Séamus Ennis:

You know, there's an awful lot to be said

for this Irish traditional

folk music and folklore, because

first of all

you have to learn it

and first you must learn the Talk

and then you must learn the Grip

and after that you must learn the Truckly-How

and then

you have the whole lot

only just to keep on practising it.

Séamus Ennis' poem metaphorically describes the path to knowledge in Irish traditional music, in his opinion, which involves an ordered progression from:

1. Learning the Talk: sounds, ornaments, articulations, music components, variations - not to mention vocabulary and language used to describe Irish musical attributes and elements; then,

2. Learning the Grip: building an embodied knowledge base through informed body movements to produce authentic sounds; and finally,

3. Learning the "Truckly-How," or the philosophical "why" of the musical tradition.

Ennis' poem ends with the notion that once a musician has obtained all three, presumably their understanding of the tradition is at a high-enough level, the only way to progress further is to "keep on practising it." Metaphors commonly used to describe "traditional" knowledge in an individual is to say they are "steeped" in tradition or that their music is "infused" with some quality stemming from their vast store of knowledge. These tea-based metaphors largely reflect the pervasive view that depth and breadth of knowledge takes time and is built slowly over the course of an individual's life experiences, much like the tea bag slowly diffuses in hot water to build flavor.

This view of the process of knowledge building over time is described by 
the Clare-style Irish fiddler interviewed as a part of the research study detailed in the "Windows" of Time part I:

I take in the information, I store the information, and in turn I'm storing up my musical knowledge and because I do that, I think - after a while, if you turn a tap on, it [knowledge] starts to flow. So as you go along, gathering information, in turn building up your own musical knowledge, educating yourself... Because, we're students - you, and me - we're students of the music we study and play, and in your case you've had other fields of study that you've done in your life. And you become a better student of the music you're playing - you're a better student than you were twenty years ago; I'm a better student today than I was twenty years ago. (...) I think over time, windows open to you, where you can put yourself into the tune. I really believe that. And, I think that there are windows you [the player as an ongoing student of the music] can open, you just have to keep mushing the stuff around in your head.

The Clare-style Irish fiddler also remarked on what musical knowledge is and how to build it, and touches on aspects invoked by Ennis' three progressive components of knowledge building:

(...) that's another huge question. ...it does help to be able to play the instrument that you play; that means you've put the time in to be able to play the instrument that you play. And, you have something to offer people, when they come to you for lessons. To be able to play means you have an understanding, and you can help other people. The other thing is, it's having the experiences of having listened to people...in my case, I've met a lot of them, I listened to them in person, and I listened to the old music again [78s and reel-to-reel tapes].

Learning repertoires of ornamentation, repertoires of [melodic] variation...the concept of variation - where does it come from? ... How you vary a melody by staying within the structure that you're in, versus looking outside the structure - that's a huge one right there. If you want to stay within the structure, you have to have reference points from within the structure, which means you have to study the field within that structure so 
that you can get a feel for what might be happening along the way [in the tune structure]. Having some understanding of the singing traditions [seannós, especially]; having some understanding of slow music [slow airs based upon sean-nós songs]; having an interest in playing slow music...playing all kinds of music, really (...)

Time factors into the fiddler's description of musical knowledge and how knowledge is built, both by way of historical perspective of the music and its performers. In ongoing practice, temporal epistemology in musicians accounts for the dynamic shifts in musical intentions, sonic outputs over time, and teaching approaches. Alluding to temporal epistemology's impact on sonic outputs over time - in other words, why the "same" tune played by the "same" musician sounds different at different points in their lifetime - Carson asks, "But do we ever fully know a tune, or only versions of it, temporary delineations of the possible?" [emphasis in original] (1996, p. 2). While implicitly referring to the Irish traditional musician's improvisational role in creating the tune, Carson's use of the phrase "temporary delineations of the possible" underscores the dynamic nature of musical knowledge and its products.

Tomás Ó Canainn - piper, long-time lecturer at University College Cork, and author of one of the earliest books aimed at describing the norms of Irish music to those outside the tradition, The Music of Ireland - also published a book of his memoirs in 1996 titled A Lifetime of Notes. In this memoir, each chapter is a story encapsulating periods of Ó Canainn's life, with an emphasis on music and teaching. When describing background information related to particular tunes, he writes:

If you are not a traditional music performer, you may not realise that every tune is weighted with memories of places and people - different places, different people -sometimes happy, sometimes sad. Maybe that is what breathes life into music, making it so much more than the sum total of its notes. Stop the ship - I think I have just learned something! (1996, p. 185).

Ó Canainn's explanation of how a musician's memories are inseparable from the traditional tunes they play, implicates time in this process.

Time is discussed explicitly by Micheál Ó Súilleabháin, pianist and founder of University of Limerick's traditional music degree programs. Ó Súilleabháin's essay on music, dance, and identity in contemporary Ireland makes a distinction between two types of time, what he terms tempus and templum: 
The idea of the 'temporal' world (from the Latin tempus: time) invites a notion of operating in some kind of human time-an important and necessary but grounded version of being in the world. Coincidentally, there is a second meaning to the English word 'temporal'-'pertaining to the temple' from the Latin templum-a consecrated space. We might speak then of being in the tempus of the world or being in the templum of the world. Two different kinds of consciousness (...) (1998, p. 80).

Husserl is known for his phenomenology of time-consciousness, which views an individual's internal perception of time as flowing rather than objective. Husserl called this perception "lived" or "phenomenological" time (Kates, 1970, p. 93). Smith asserts of Husserl's view on memory of past events in the present consciousness: "Husserl insists that the presence of the past through retention cannot be a mere image of the past in the present but must be a perception of the past itself. Retention is the persistence of the very being of the past. Retention is the constitution of the persistent identity of past events, such as notes and melodies, themselves" (emphasis added, 1996, p. 288).

If the presence of the past goes beyond the purpose of acting as an image or sign, then it takes on new meaning as the process of knowledge building modifies a subject's temporal epistemology. Tribble and Sutton write on memory: “...The remembering mind is both in its own firmly located time and place, participating in the complex allure of the moment, and always also slipping into what is absent, or merging with other times and places which are already seeping through." (2012, p. 589). The epistemic view in the present re-interprets the past memory and gives it meaning relative to the current view; the memory both reflects the present epistemic viewpoint and the past epistemic viewpoint as it is explained and described by the practitioner.

\section{Epistemology as Dynamic Experience}

Experience is what feeds and morphs a musician's temporal epistemology, which can then be accessed only through oral documents related to musical practice - memories, metaphors, and stories - by those outside the musician. Temporal epistemology has enduring impact on the musician's sonic outputs, making them unique each time even if the idea is to play the "same" tune. Of embodiment and memory, Tribble and Sutton note that, "To focus on memory is to address the complex bridges between the embodied sensory-affective realm of individual 
experience and the social and material constituents of our activities of remembering. Such memory practices have neural, phenomenological, technological, and interpersonal dimensions, with their own distinctive histories and dynamics" (2012, p. 589). The documents are grown from musicians' experience, making the tune a unique entity-for even though the "same" tune is being played at different points in time, the tune is not the same on a sonic (notebased), creative (use of ornaments or variations), or fundamental level.

\section{Epistemology in Musical Practice}

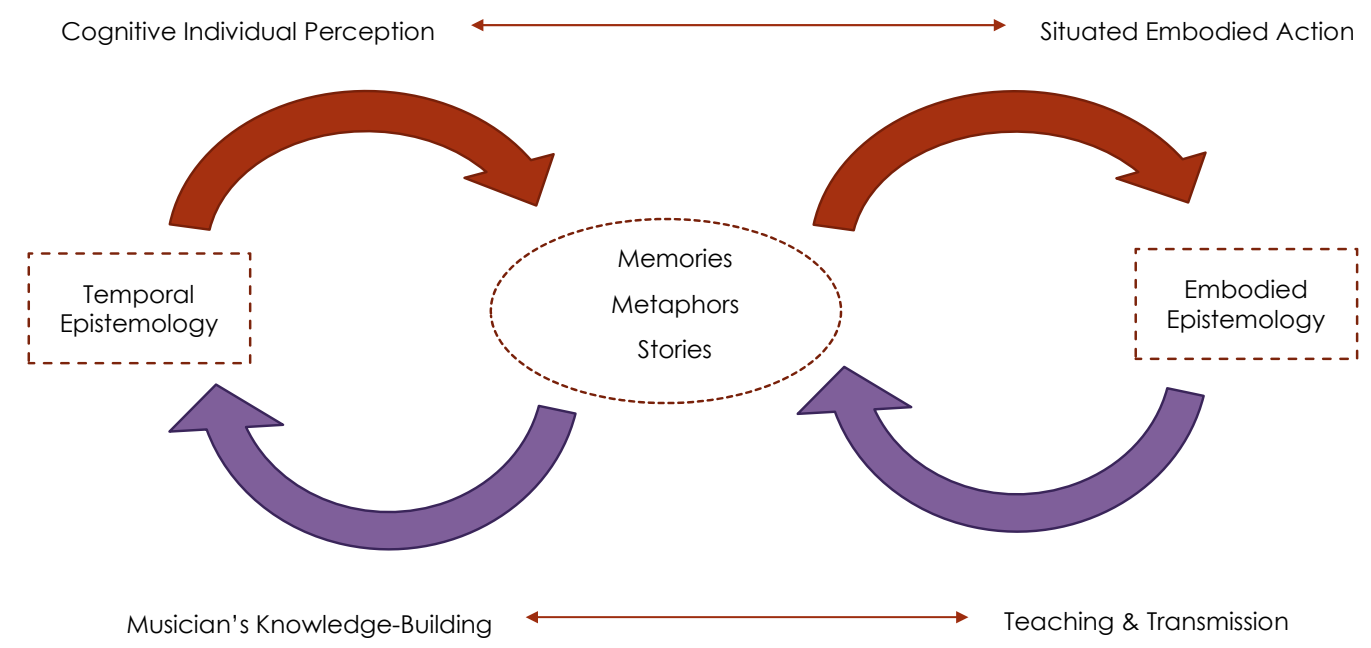

Figure 1: The documents' position as influencer-informant to and influencedinformed by temporal and embodied epistemology.

Documents - in this case, memory, metaphor, and stories - both contribute to and provide evidence to an individual's temporal epistemology. This positions the documents as influencer-informant to and influenced-informed by temporal and embodied epistemology. They are used to provide access to epistemic views at specific points in time and act as time-spanning devices. Additionally, they serve to reinforce or modify temporal epistemology.

In the larger act of making music, these documents give meaning to situated embodied actions which in turn informs the use of these same documents in 
teaching and transmission contexts. They act as mediators between cognitive individual perception and situated embodied action. The use of temporal documents in transmission also reflexively influences the musician's own knowledge-building process. Tribble and Sutton examine temporal aspects to embodied cognition within the domain of memory studies, noting "certain forms of embodied memory like gesture, kinaesthesis, and bodily skill are arguably the primary domains of polytemporality" (2012; p. 590).

Relating to another document, metaphor, Johnson and Lakoff adhere to their view that conceptual metaphor is inseparable from its embodiment: "You cannot simply peel off a theory of conceptual metaphor from its grounding in embodied meaning and thought. You cannot give an adequate account of conceptual metaphor and other imaginative structures of understanding without recognizing some form of embodied realism." (2002, p. 245). Regarding embodiment, Bowes and Katz note Richie's (2006) view that "metaphor has its origins in social interactions, such as speech, and that processing metaphor, even when presented without context...evokes an extralinguistic context involving past memories, thoughts, and emotions" (2015, p. 962).

\section{Conclusion}

To music practitioners, in discussing knowledge processes in their traditions, memory, metaphor, and storytelling documents serve a variety of purposes - from reinforcing or repeating pervasive cultural narratives, to recounting transformative encounters with information and/or epistemic viewpoints. One of their main purposes is to present a "window" into their epistemic view at a point in time, to be re-interpreted and re-negotiated as they continue to practice their cultural tradition. The three documents have fluid boundaries, making them not distinct entities but rather types of devices that - when coupled with documentary properties (Frohmann, 2004) constitute a type of document to the music practitioner.

Further research into craft domains and their practitioners' temporal and embodied epistemologies will increase understanding of the relationship between embodiment, temporal epistemology, and the documents used to provide evidence into these ongoing processes. These "craft" domains - such as culinary professionals (chefs), luthiers or instrument makers, and master craftsmen - are knowledge domains that involve both artistry and technical craftsmanship, while largely reliant on apprentice-based learning models. As suggested in Part I of this 
paper, researching master-apprentice relationships and the apprenticeship model at large will allow for in-depth exploration of epistemology in embodied and situated contexts.

Temporal epistemology accounts for the musician as a dynamic entity whose outputs vary like that of a master craftsman: the same tools are used to produce the same manifestation of the craft; however, the individual has changed from time-experience and therefore the output will vary because of the impact of temporal epistemology. Because of this, temporal epistemology needs to be considered when answering the question, "What is a document?"

\section{References}

Bowes, A., \& Katz, A. (2015). Metaphor creates intimacy and temporarily enhances theory of mind. Memory \& Cognition, 43(6), 953-963.

Carson, C. (1998). Last night's fun: In and out of time with Irish music. New York: North Point Press.

Frohmann, B. (2004). Documentation redux: Prolegomenon to (another) philosophy of information. Library Trends, 52(3), 387-407.

Johnson, M., \& Lakoff, G. (2002). Why cognitive linguistics requires embodied realism. Cognitive Linguistics, 13(3), 245-264.

Kates, C. A. (1970). Perception and temporality in Husserl's phenomenology. Philosophy Today, 14(2), 89-100.

Ó Canainn, T. (1996). A lifetime of notes: The memoirs of Tomás Ó Canainn. Cork: Collins Press.

Ó Súilleabháin, M. (1998). "Around the house and mind the cosmos:” Music, dance and identity in contemporary Ireland. In R. Pine (Ed.), Music in Ireland, 1848-1998: Thomas Davis lectures (pp. 76-86). Boulder, CO: Mercier Press.

Ritchie, D. L. (2006). Context and connection in metaphor. New York: Palgrave MacMillan.

Smith, J. (1996). Husserl, Derrida, Hegel, and the notion of time. International Philosophical Quarterly, 36(3), 287-302.

Tribble, E. B., \& Sutton, J. (2012). Minds in and out of time: Memory, embodied skill, anachronism, and performance. Textual Practice 26(4), p. 587-607. doi:10.1080/0950236X.2012.696485

Weissenberger, L. K. (2015). Traditional musics and ethical considerations of knowledge and documentation processes. Knowledge Organization, 42(5), 290-295. 
Weissenberger, L. K. (2016). "Windows" of time: Memory, metaphor, and storytelling as documents. Proceedings from the Document Academy, 3(1), Article 11. 